\title{
GREEN SUPPLY CHAIN MANAGEMENT FOR CONSTRUCTION WASTE: CASE STUDY FOR TURKEY
}

\author{
T. BELDEK ${ }^{1}$, H. CAMGÖZ-AKDAĞ ${ }^{1} \&$ E. HOŞKARA ${ }^{2}$ \\ ${ }^{1}$ Department of Management Engineering, İstanbul Technical University, Turkey \\ ${ }^{2}$ Department of Architecture, Eastern Mediterranean University, Cyprus
}

\begin{abstract}
As the construction industry is growing rapidly, managing a project becomes more vital. The three major parameters to be optimised for a project are content, time and cost to reach a high level of quality. These parameters are also essential for a construction project to satisfy customers on time. Today, it is also critical to protect the environment either at a manufacturing or at a construction site. Environmental problems and the growth of construction industry cause a new topic to manage construction waste with the help of green supply chain management (GSCM). GSCM reduces energy usage and waste, so it prevents any problem that will occur in human health and environment. To decrease waste with the help of GSCM in construction site, waste management regulations must be set to force the producers and consumers for its application. The European Union Council published a waste management directive in 2008 that gives some goal numbers to manage construction waste to minimise the environmental effect. The goal is to reach a reduction of $70 \%$ of construction and demolition waste (CDW) that will be reused, recycled or recovered in 2020. The aim of this study is to explore the cost-benefit and socialbenefit reflections of GSCM practices in Turkey under the influence of recent government mandated regulations with an emphasis on green supply chain and reverse logistics in CDW compared to EU 2008 directive. As Turkey is a candidate EU member, this study is analysing how close it is to the directives mentioned above. A GSCM flow chart is established to understand the CDW management system clearly in Turkey. Based on the literature review and case study examples from Turkey a model is built and propositions regarding GSCM and reverse logistics are formulated.
\end{abstract}

Keywords: construction management, EU, green supply chain management, Turkey, waste management.

\section{INTRODUCTION}

Global warming and industrialisation causes more and more pollution which made environment friendly systems even more popular. It is vital to leave a healthy environment for the next generation. In this context, 'sustainability' is very important for any type of process even if it is a production line or a service department. Today, a huge amount of construction waste is being generated according to the growing construction industry. Human life may be affected from construction and demolition waste (CDW) negatively with different aspects, such as air, land or noise pollution. For this reason, building sustainable constructions and managing CDW is vital.

European Union Council published the waste directive in 2008 which includes different types of waste definitions and action plans. Literature review shows that green supply chain management (GSCM) is a new topic for the Turkey construction industry compared to EU countries. In Turkey, regulation about excavation soil and CDW is not clear in practice. The regulation does not give goals but gives reference to the EU Waste Management Directive. As a candidate EU country, Turkey should apply similar management systems for waste 
management. This study analyses the current situation of the supply chain management (SCM) in the construction industry and makes suggestions for optimising the cost and making the chain sustainable.

\section{LITERATURE REVIEW}

\subsection{Supply chain management}

SCM definition changes day-by-day according to its broadening scope [1]. SCM includes logistics and trade while operating both customers and suppliers [2]. Supply chain is a cycle that starts from suppliers and ends at customers as the product or service flow [3]. Another definition is that supply chain is the network of organisations that are involved, through upstream and downstream linkages, in the different processes and activities that produce value in the form of products and services delivered to the ultimate consumer [4].

Supply chain traditionally starts from the cradle to the grave, which means from raw material state till the end product reaching the customer. However, today environmental issues force processes to change and come up with new operations such as recovery options. For this reason, closed-loop supply chain, a new definition, allows the finished good collected from customers which are end-of-life products now, and go in to some other processes for recovering them [5]. The aim of the end-of-life recovery options is to recover material, energy and avoid landfill. This recovery is a value. If it is managed properly, high profits will be gain for both producers and customers [6].

Today companies are aware of their responsibilities about the environment depending on regulations. This leads to sustainable systems that will continue their processes without giving any harm to the environment. Environmental issues are seen at every step of supply chain that starts from getting the raw material and ends with reuse or recycle or disposal [7]. This causes a requirement for companies to have a GSCM. A study in India, found that there are different pressures for different sectors to be able to adopt GSCM in their own traditional supply chains [8]. To integrate GSCM to a company, five different applications can be used as environmental management systems, green purchasing and design, investment recovery and strong relations with customers [7]. Common green activities and sustainability have an intersection in practice which is $4 \mathrm{R}$ : reduction, redesign, reuse and remanufacture [2].

\subsection{GSCM and construction industry}

Constructions cause air, water and noise pollution and today with global warming environmental issues became very important. Even in construction design, green materials are being preferred to minimise waste and construction firms are starting to use GSCM to make their work sustainable. Green buildings, sustainable design and constructions, construction waste management are some of the sustainability topics that are being used by producers [9]. The best way to minimise the construction waste generation is to reduce materials while designing the structure. It will also eliminate many environmental problems such as disposal. Also material types have to be selected very carefully to get rid of recycling limitations that means recyclable materials should be preferred [10].

With different stages in construction, it is possible to define and measure CDW. In the first half of the life cycle, CDW type can be defined. The first half is where the concept and the design phase including selecting suitable materials for the construction. However, in the 
second half of the life cycle, the CDW amount is measured. This amount can be gathered from the data which is already processed as a construction project and the material used in the building can be measured. Also at the end, in demolition stage, materials can be clearly seen after decomposition.

To leave a healthy environment with high level of social, economic and environmental conditions to future generations, sustainability is important which leads to improved quality of systems [11]. SCM has four specific roles in construction; improving the interface between site activities and the supply chain, improving the supply chain, transferring activities from the site to the supply chain, integration of site and supply chain. SCM helps to understand construction problems and shows a direction to solve them but practical methods for SCM should be improved to implement for specific situation of construction [12].

\section{ANALYSIS OF CWM IN TURKEY}

\subsection{Regulation on excavation soil, construction and ruin waste control}

Regulations about common waste management at Turkey are improved according to waste variation. EU directives and country-based guidelines are published and put into practice. In this scope, different types of waste are being stored regularly such as domestic solid waste, excavation soil, CDW, waste batteries and accumulators, hazardous waste, herbal waste oils, medical waste, end-of-life tires, packaging waste, polychlorinated biphenyl and polychlorinated terphenyl, waste electrical and electronic equipment, waste oil, end-of-life vehicles, maintenance and repairment equipment of vehicles [13].

One of the most important principles of Turkey's waste management strategy is to prevent waste at source, otherwise reduces waste and finally if waste is unavoidable to recycle it. Collecting all terms related to waste management directive under a common structure, simplifying regulations and adjusting them according to the EU waste management directive updates are being maintained by the Ministry of Environment and Urban Planning.

There are two issues on recycling in the 10th development plan for years 2014-2018: Industries will give attention to applications such as recycling and recovery. Recycling performance is negatively affected by some topics such as lack of knowledge about recycling benefits which is one of the important issues in the solid waste management, lack of standardisation of the recovered secondary products, deficiency of incentives and orientation system.

According to the national data about recycling; at 2003, at 46 recovery centres nearly 4,000 people were employed and as a result of recovery operations 62 million TL added value provided. At 2011, at 898 recovery facility nearly 60 thousand people were employed and as a result of recovery operations the provided added value exceeded 1 billion TL [13].

'Regulation on Excavation Soil, Construction and Ruin Waste Control' is law in force that was promulgated at 18.03.2004. Following goals are given in the regulation: Reduce excavation, construction and ruin waste without giving harm to the environment at the place where they are produced, collect, store temporarily, transport, recover, use and dispose them.

Firstly to reduce excavation soil and construction/demolition waste at source, reuse, collecting separately, recovery and especially evaluating as infrastructure material are essentials. It is also essential not to mix the excavation soil and construction/demolition waste. To make a good system for recycling, removing is important by separating waste at the source and making 'selective destruction'. Recovered products, with respect to the standards, are used 
with original materials or separately at new concrete production, road, parking lot, pavement, walking roads, drainage works, sewer pipe and as filling material at cable laying, lower and upper building construction, sports and game centre construction and other filling and recreation works primarily. Construction/demolition waste that cannot be recovered are used as daily covering material in storage areas after required separation and sizing. Permitting authority is given to the city and district municipalities in the urban area, metropolitan municipalities in metropolitans and district municipalities for which cities are not metropolis [13].

\subsection{Current supply chain model}

Istanbul Metropolitan Municipality Directorate of Environmental Protection manages CDW according to the Turkish regulation.

First of all, contractor defines the waste amount of the construction or demolition and applies to the district municipality with a $70 \mathrm{TL}$ valued receipt to get acceptance form while showing the construction/demolition license. This form must be filled by the contractor who is the producer of the construction (or demolition), transporter (logistics firm) and storage firm. Trucks that will carry CDW must register to the 'Vehicle Tracking System (VTS)' and the firm must get the transportation license. VTS is not included in the regulation but it is active according to the act of the parliament. Only vehicles which are registered to the VTS can get the transportation license from Istanbul Metropolitan Municipality Directorate of Environmental Protection. Trucks which have lift system will be registered to the VTS and they have to be yellow, on their sides there cannot be any kind of symbols and also the license plate and 'excavation soil and CDW transporter' must be written on both sides of the truck. In the regulation, it mentions about containers that will be in front of the construction (or demolition) site but in practice there are dumper trucks instead of containers for waste. Today construction firms in Turkey usually use subcontractors to transport CDW to storage areas. They have to take permission from municipalities to send their waste to the pre-defined areas according to the capacity of the landfill. In Istanbul, ISTAC is the only company that manages landfills and recycling operations in the construction industry. ISTAC is an affiliate of Istanbul Metropolitan Municipality, which works according to the national and international standards [14].

Figure 1 shows current supply chain model for a construction firm in Turkey. In this model, firm sends CDW to the land fill and the process finishes. This means that firm does not get

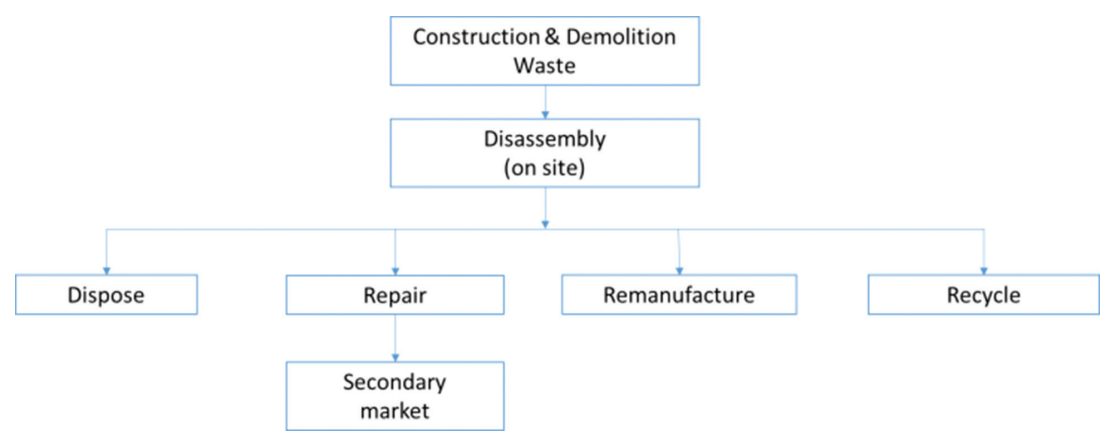

Figure 1: Current supply chain model for a construction firm in Turkey. 
Table 1: Annual excavation soil and CDW amounts that are disposed or recovered, and administrative sanctions.

\begin{tabular}{llrrrrrr}
\hline & \multicolumn{1}{c}{ Unit } & 2010 & 2011 & 2012 & 2013 & 2014 & Total \\
\hline $\begin{array}{l}\text { Disposed excavation } \\
\text { soil amount }\end{array}$ & $\begin{array}{l}\text { Thousand } \\
\text { tons }\end{array}$ & 24.100 & 47.709 & 52.455 & 65.502 & 69.999 & 259.765 \\
$\begin{array}{l}\text { Disposed CDW } \\
\text { amount }\end{array}$ & Tons & 5.361 & 5.680 & 5.152 & 0 & 0 & 20.451 \\
$\begin{array}{l}\text { Recovered excavation } \\
\text { soil amount }\end{array}$ & $\begin{array}{l}\text { Thousand } \\
\text { tons }\end{array}$ & 34 & 36 & 284 & 280 & 221 & 855 \\
$\begin{array}{l}\text { Recovered CDW } \\
\text { amount }\end{array}$ & Tons & 73.200 & 116.952 & 15.695 & 14.312 & 0 & 220.159 \\
$\begin{array}{l}\text { Administrative } \\
\text { sanction }\end{array}$ & Piece & 1.482 & 887 & 716 & 439 & 320 & 3.844 \\
& Million TL & 55 & 45 & 29 & 30 & 26 & 185 \\
\hline
\end{tabular}

any profit from their own waste, and those waste may give harm to the environment if they are stored at a landfill.

Annual CDW amount is given at Table 1 that is taken from Istanbul Metropolitan Municipality Directorate of Environmental Protection [15].

\subsection{Cost analysis}

Construction firms pay money to take the required permission forms from the municipality, to transfer their waste to the landfills, but with the disassembly operation on site, they sell some valuable materials to the secondary markets. Table 2 shows the price scale taken from Istanbul Metropolitan Municipality Directorate of Environmental Protection [15].

\section{ANALYSIS OF CWM IN EU COUNTRIES}

Waste generation is increasing day-by-day at many countries due to the growth of towns and cities. Many regulations about CDW management are developed to prevent the environment [16].

\subsection{Directive 2008/98/EC of the European Parliament and of the council}

Directive 2008/98/EC starts with waste, recycling and recovery definitions. It also explains how waste can be classified to be a secondary material or product. The aim of the waste management is protecting the environment without giving harm to human health, animals or plants, water, air and soil.

CDW is nearly $30 \%$ of total waste which is generated in European Union. CDW includes many kind of recyclable material such as excavation soil, metals, asbestos, plastics and so on [17].

Directive 2008/98/EC gives a strict goal for CDW that by 2020, $70 \%$ of construction weight has to be recovered. Size or type of the construction does not change this goal that 
Table 2: Price scale for construction waste storage and transportation.

\begin{tabular}{|c|c|c|}
\hline $\begin{array}{l}\text { Excavation Soil, CDW Storage License, Recycling Center License and } \\
\text { Reuse and Recycle of Excavation Soil Price Scale }\end{array}$ & Unit & Offer (TL) 2015 \\
\hline Mentioned in the Project per $\mathrm{m}^{3}$ & $\mathrm{~m}^{3}$ & 0,8 \\
\hline Recycling Center License & piece & 7,200 \\
\hline Temporary Storage of Excavation Soil Price Scale & Unit & Offer (TL) 2015 \\
\hline Per $\mathrm{m}^{3}$ & $\mathrm{~m}^{3}$ & 0,35 \\
\hline Excavation Soil and CDW Transportation License Price Scale & Unit & Offer (TL) 2015 \\
\hline Per 1 truck & vehicle & 165 \\
\hline Loss, stolen and wear renewal (per 1 truck) & vehicle & 55 \\
\hline Excavation Soil and CDW Transportation Voucher Price Scale & Unit & Offer (TL) 2015 \\
\hline Per piece & piece & 3,5 \\
\hline Excavation Soil and CDW Transportation Voucher Price Scale & Unit & Offer (TL) 2015 \\
\hline Per piece & piece & 3,5 \\
\hline $\begin{array}{l}\text { Excavation Soil and CDW Transportation and Acceptance Form Price } \\
\text { Scale }\end{array}$ & Unit & Offer (TL) 2015 \\
\hline $\begin{array}{l}\text { Excavation Soil and CDW Transportation and Acceptance Form: } \\
1 \text { piece ( } 4 \text { copies) }\end{array}$ & piece & 75 \\
\hline Excavation Soil and CDW Storage Price Scale & Unit & Offer (TL) 2015 \\
\hline Price scale of storage per ton at landfills which have weighbridge & tons & 7 \\
\hline Type of vehicle up to $5 \mathrm{~m}^{3}$ which arrives to the landfill ( $5 \mathrm{~m}^{3}$ included $)$ & vehicle & 30 \\
\hline $\begin{array}{l}\text { Type of vehicle between } 5 \mathrm{~m}^{3}-10 \mathrm{~m}^{3} \text { which arrives to the landfill } \\
\text { (10 } \mathrm{m}^{3} \text { included) }\end{array}$ & vehicle & 45 \\
\hline $\begin{array}{l}\text { Type of vehicle between } 10 \mathrm{~m}^{3}-18 \mathrm{~m}^{3} \text { which arrives to the landfill } \\
\left(18 \mathrm{~m}^{3} \text { included }\right)\end{array}$ & vehicle & 80 \\
\hline Type of vehicle more than $18 \mathrm{~m}^{3}$ which arrives to the landfill & vehicle & 105 \\
\hline Excavation Soil and CDW Transportation Price Scale & Unit & Offer (TL) 2015 \\
\hline Transportation of 1 ton of excavation for $1 \mathrm{~km}$ (depreciation+fuel) & $\mathrm{t} 1 /$ tons $-\mathrm{km}$ & 0,55 \\
\hline Excavation Soil and CDW Collection Price Scale & Unit & Offer (TL) 2015 \\
\hline $\begin{array}{l}\text { Collection vehicle which has } 5 \mathrm{~m}^{3} \text { capacity, with } 50-60 \mathrm{~kg} \text { bags up to } \\
20 \text { bags per truck }\end{array}$ & vehicle & 70 \\
\hline $\begin{array}{l}\text { Collection vehicle which has } 5 \mathrm{~m}^{3} \text { capacity, with } 50-60 \mathrm{~kg} \text { bags more } \\
\text { than } 20 \text { bags, for per extra bag }\end{array}$ & piece & 10 \\
\hline
\end{tabular}

every project must reach it in 5 years. It seems to be strict but it is very important to manage those CDW to protect human health and the environment.

\subsection{Supply chain models in EU countries}

It is difficult to manage CDW in EU because of strict goals which are mentioned before. A study showed that Southern Europe countries need development in their measures, and 


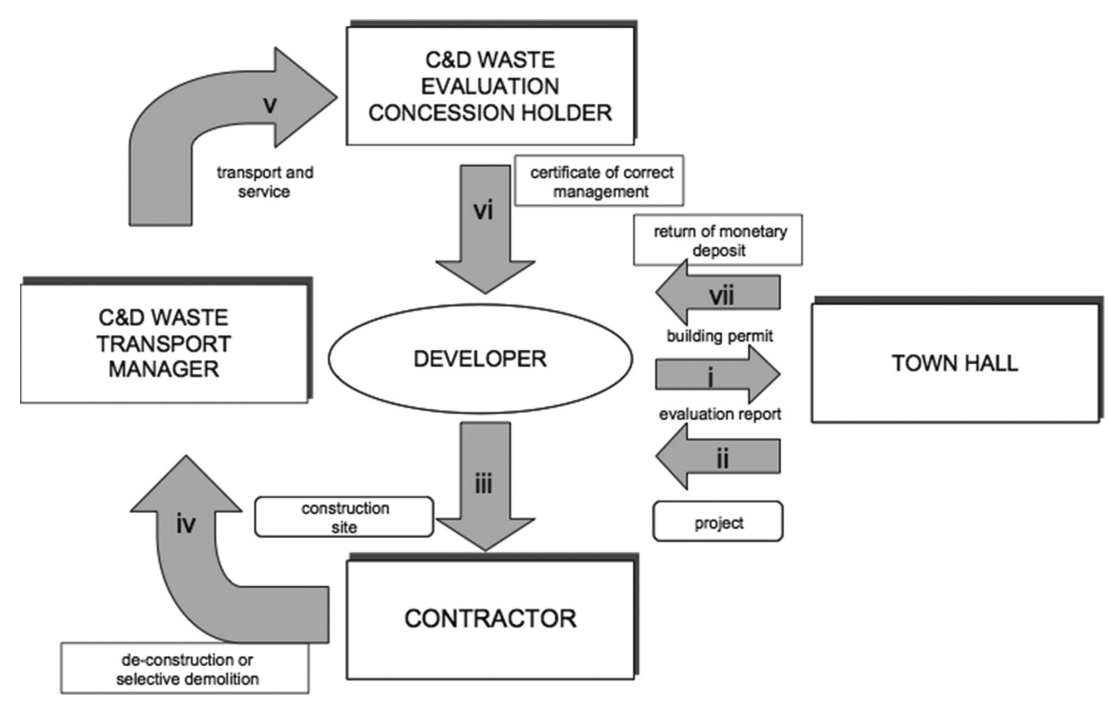

Figure 2: Construction and demolition waste management model used in Spain.

Central and Northern countries need new models to integrate waste management technologies locally, so that waste management systems will work efficiently to be able to reach those governmental goals [18]. CDW management regulation was published in Spain, and it was tested in the Seville area. In Fig. 2, the closed-loop system can be seen that is known as Alcores model for waste management. This system allows CDW to be checked and operated and also recycled [16].

This example shows a great auto-control for a firm in Spain. They operate every SCM steps, and after transportation they again check the validity if the management tools are used properly or not.

\section{DISCUSSION}

It is obvious that construction waste management in Turkey has some deficiencies compared to EU countries. Discussion part will analyse the difference between the regulations that are published in Turkey and European Union Countries. According to those differences, a new supply chain model will be conducted and an optimisation model will be solved to minimise the cost of construction waste management.

\subsection{Comparison of Turkey and EU waste management directives}

In terms of waste management, European Union has published a directive (2008/98/EC) which gives details about goals for EU countries according to different types of waste. After giving the definition of waste, to standardise waste management at EU countries, the directive mentions the objectives as follows: 'In order to comply with the objectives of this Directive, and move towards a European recycling society with a high level of resource efficiency, Member States shall take the necessary measures designed to achieve the following targets: 
1. By 2020, the preparing for re-use and the recycling of waste materials such as at least paper, metal, plastic and glass from households and possibly from other origins as far as these waste streams are similar to waste from households, shall be increased to a minimum of overall $50 \%$ by weight;

2. By 2020, the preparing for re-use, recycling and other material recovery, including backfilling operations using waste to substitute other materials, of non-hazardous CDW excluding naturally occurring material defined in category 170504 in the list of waste shall be increased to a minimum of $70 \%$ by weight' [19].

Turkey is not a member of EU but candidate ministries are trying to edit regulations according to the EU standards. In 2008, ministry of environment and forestry published a waste management action plan that includes 4 years for each city in Turkey. It stated goals for cities to manage solid and hazardous waste types to protect environment and human health. There is no goal like gaining $70 \%$ of materials with recycling at 2020 which is mentioned in the EU Directive, for Turkey in the related regulation. At Turkey, every year 125 million tons of excavation soil is evaluated to regain. At the current situation, CDW amount is nearly $4-5$ million tons per year. With the new regulation of rehabilitation of areas that are under risk of disasters for the first 3 years, annual goal will be $40 \%$ that is 10 million tons/ year and 6 million tons/year for regaining materials [13].

\subsection{Developed supply chain model}

A closed-loop supply chain will be sustainable for the construction industry that will also suit the definition of GSCM explained above. The following model will reduce the disposal amount of waste material with the help of recycle, repair and remanufacture operations. Figure 3 shows the developed supply chain model for a construction firm in Turkey. By this model, construction firm will able to sell their recovered materials to the secondary markets and get profit from them. In the previous model, firm was not able to know what is happening to their waste after sending them to the landfill. Thus, this new model will be sustainable for the environment that materials will not left on the ground while giving harm to the environment.

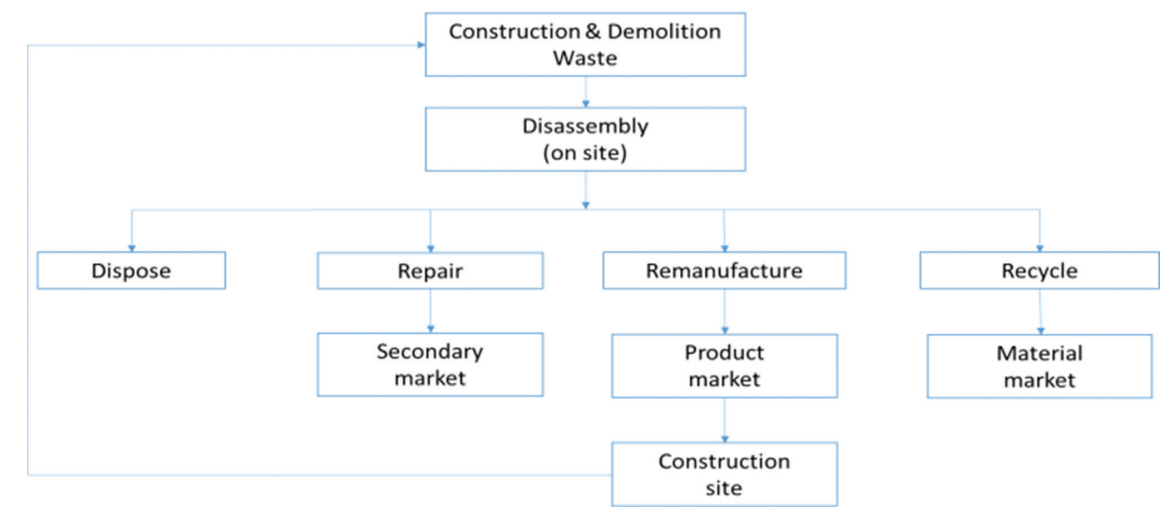

Figure 3: Developed closed-loop supply chain model. 


\section{CONCLUSIONS AND RECOMMENDATIONS}

The aim of this study was to explore the cost-benefit and social-benefit reflections of GSCM practices in Turkey under the influence of recent government mandated regulations with an emphasis on green supply chain and reverse logistics in CDW compared to EU 2008 directive. A GSCM flow chart was established to understand the CDW management system clearly in Turkey. Based on the literature review and case study examples from Turkey a model was built and propositions regarding GSCM and reverse logistics were formulated.

To conclude this study, there are some numerical differences between the regulations of Turkey and European Union. As there are no target numbers in the excavation soil and CDW management regulations for Turkey, the construction firms has no idea of what are the consequences of the waste sent to the landfill.

To make the supply chain sustainable, in the design phase of a construction, the materials may be used less and green materials may be preferred. As mentioned in the regulations, the first aim has to be to reduce waste, so it may be done with using less raw material if it is possible.

After reducing waste, the next step is to do recovery operations for the CDW. If the construction firm is responsible for the waste and if they can make their supply chain closed, they will also be able to re-use those secondary raw materials and remanufactured products in their own site.

The other alternative is to sell those secondary materials to the market. At future studies, customer points can be added to sell the recovered products that the firm will not use them on their site or remaining products.

For further research, a capacitated linear mathematical model which includes multi-product, multi-recovery and multi-manufacturing options, can be developed for construction firm to be able to use their own recovered products at their own construction sites.

Finally, it can be said that if these above-mentioned improvements are applied as setting a supply chain for construction industry, the system will be sustainable and the construction firm will be able to minimise the cost while making profit from their own waste.

\section{REFERENCES}

[1] Parkhi, S., Joshi, S., Gupta, S. \& Sharma, M., A study of evolution and future of supply chain management. Supply Chain Management, 9(2), pp. 95-106, 2015.

[2] Wang, H. \& Gupta, S., Green Supply Chain Management, Product Life Cycle Approach, McGraw Hill, 2011.

[3] Bachok, S., Khuzzan, S.M.S., Jaafar, S. \& Baharudin, H., Construction supply chain management and coordinated design drawings: an outlook of the construction industry and sustainable urban planning. In 9th International Symposition on Planning \& IT, Vienna, pp. 67-84, 2004.

[4] Christopher, M. \& Martin L., Logistics and Supply Chain Management, Pitman Publishing: London, 1992.

[5] Beamon, B.M., Designing the green supply chain. Logistics Information Management, 12(4), pp. 332-342, 1999. http://dx.doi.org/10.1108/09576059910284159

[6] Guide, V.D.R. \& Van Wassenhove, L.N., Closed-loop Supply Chains, Working PapersInsead R and D, 2000. 
[7] Zhu, Q. \& Sarkis, J., An inter-sectoral comparison of green supply chain management in China: drivers and practices. Journal of Cleaner Production, 14(5), pp. 472-486, 2006.

http://dx.doi.org/10.1016/j.jclepro.2005.01.003

[8] Xu, L., Mathiyazhagan, K., Govindan, K., Haq, A.N., Ramachandran, N.V. \& Ashokkumar, A., Multiple comparative studies of green supply chain management: pressures analysis. Resources Conservation and Recycling, 78, pp. 26-35, 2013. http://dx.doi.org/10.1016/j.resconrec.2013.05.005

[9] Yuan, H., A model for evaluating the social performance of construction waste management. Waste Management, 32(6), pp. 1218-1228, 2012. http://dx.doi.org/10.1016/j.wasman.2012.01.028

[10] Begum, R.A., Siwar, C., Pereira, J.J. \& Jaafar, A.H., A benefit-cost analysis on the economic feasibility of construction waste minimisation: the case of Malaysia. Resources Conservation and Recycling, 48(1), pp. 86-98, 2006. http://dx.doi.org/10.1016/j.resconrec.2006.01.004

[11] Ortiz, O., Castells, F. \& Sonnemann, G., Sustainability in the construction industry: a review of recent developments based on LCA. Construction and Building Materials, 23(1), pp. 28-39, 2009.

http://dx.doi.org/10.1016/j.conbuildmat.2007.11.012

[12] Vrijhoef, R. \& Koskela, L., The four roles of supply chain management in construction. European Journal of Purchasing \& Supply Management, 6, pp. 169-178, 2000. http://dx.doi.org/10.1016/S0969-7012(00)00013-7

[13] Ulusal Geri Dönüşüm Strateji Belgesi Ve Eylem Plani 2014-2017, ÇS $\square$ B, 2012-1.

[14] http://www.istac.com.tr/corporative/history.aspx, (date retrieved 30 April 2015).

[15] Istanbul Metropolitan Municipality Directorate of Environmental Protection, personal communication, April 20, 2015.

[16] Solís-Guzmán, J., Marrero, M., Montes-Delgado, M.V. \& Ramírez-de-Arellano, A., A Spanish model for quantification and management of construction waste. Waste Management, 29, pp. 2542-2548, 2009.

[17] http://ec.europa.eu/environment/waste/construction_demolition.htm, (date retrieved 17 July 2015).

[18] Pires, A., Martinho, G. \& Chang, N., Solid waste management in European countries: A review of systems analysis techniques. Journal of Environmental Management, 92, pp. 1033-1050, 2011.

http://dx.doi.org/10.1016/j.jenvman.2010.11.024

[19] Directive 2008/98/Ec of the European Parliament and of the Council of 19 November 2008. 